Jurnal Inkofar * Volume 5 No. 2, Desember 2021 * ISSN: 2615-3645 (Print) / ISSN: 2581-2920 (Online)

Tersedia secara online di: http://www.politeknikmeta.ac.id/meta/ojs/

\title{
PERANCANGAN MAKET PROSES PRODUKSI (MOLD PRODUCTION PROCESS) DENGAN MESIN 3D PRINTING SEBAGAI MEDIA PEMBELAJARAN
}

\author{
Fransisca Debora ${ }^{1}$, Rizki Arya ${ }^{2}$, Suheri $^{3}$, Supriyati $^{4}$
}

\footnotetext{
${ }^{1}$ Program Studi Teknik Industri / Politeknik META Industri Cikarang / sisca@politeknikmeta.ac.id

${ }^{2}$ Program Studi Teknik Industri / Politeknik META Industri Cikarang / arya@ politeknikmeta.ac.id

${ }^{3}$ Program Studi Teknik Industri / Politeknik META Industri Cikarang / suherimeta.ti17@gmail.com

${ }^{4}$ Program Studi Teknik Industri / Universitas Pelita Bangsa / supriyati0181@gmail.com
}

\begin{abstract}
Learning media is a vehicle for distributing messages and learning information, one of which can be in the form of mockups. A mockup is a miniature imitation in a small size that is useful for describing a place or situation, which will be created as desired. One of the private universities that has an Industrial Engineering study program has learning that requires mockups to describe the real state of the industry. This mockup is needed to describe process requirements, production flow, machine requirements, human needs, layout, and so on. The mock-up design process in this research uses a case study of the mold industry process using a production flow layout type. This production flow is used to clearly describe the need for process sequences and production operations in the mold industry. The design of the mockup is done using a 3D printing machine. The use of $3 D$ printing also supports the application of Industry 4.0 in mastering additive technology.
\end{abstract}

Keywords : Mockup, Layout, Design, Mold Production, 3D Printing Machine

\begin{abstract}
ABSTRAK
Media pembelajaran merupakan wahana penyalur pesan dan informasi belajar yang salah satunya dapat berupa maket. Maket merupakan miniatur tiruan dalam ukuran yang kecil yang bermanfaat untuk mendeskripsikan sebuah tempat atau keadaan, yang akan diciptakan sesuai dengan keinginan. Salah satu Perguruan Tinggi Swasta yang memiliki program studi Teknik Industri memiliki pembelajaran yang memerlukan maket dalam menggambarkan keadaan industri secara real. Maket ini diperlukan untuk menggambarkan kebutuhan proses, alur produksi, kebutuhan mesin, kebutuhan manusia, tata letak, dan lain sebagainya. Proses perancangan maket yang dibuat pada penelitian ini menggunakan studi kasus proses industri mold dengan menggunakan tipe layout aliran produksi. Aliran produksi ini digunakan untuk menggambarkan secara jelas kebutuhan urutan proses dan operasi produksi di industri mold. Perancangan maket yang dilakukan menggunakan mesin 3D printing. Penggunaan 3D printing ini juga menunjang penerapan industri 4.0 pada penguasaan additive technology.
\end{abstract}

Kata Kunci : Maket, Layout, Perancangan, Produksi mold, Mesin 3D Printing

\section{PENDAHULUAN}

Media pembelajaran merupakan wahana penyalur pesan dan informasi belajar yang dirancang secara baik akan sangat membantu peserta didik dalam mencerna dan memahami materi pelajaran guna mencapai tujuan pengajaran (Djamarah and Zain, 2006). Salah satu Perguruan tinggi di Cikarang memiliki kebutuhan media pembelajaran yang dapat menggambarkan aktivitas tata letak industri yang ditampilan dalam purwarupa desain maket. Jenis industri yang dipilih dalam menggambarkan tata letak industri ini yaitu jenis industri dengan proses industri mold (mold production process). Melalui desain maket visualisasai tata letak dari industri tersebut dapat direpresentasikan dalam bentuk tiga dimensi yang meniru sebuah benda atau objek yang bertujuan menggambarkan keadaan sebenarnya (Hakim, 2009). Tata letak produksi merupakan bagian yang tidak terpisah dalam proses produksi (Suminar et al., 2020). Dimana produksi merupakan aktivitas yang proses akhirnya akan menghasilkan produk yang 
bernilai tambah (Heizer and Render, 2009) yang memerlukan tata letak fasilitas yang baik dan menunjang kelancaran kegiatan produksi (Wignjosoebroto, 2009).

Pemanfaatan dari perancangan maket ini juga digunakan untuk mendukung tersedianya media pembelajaran yang dapat dimanfaatkan sebagai bahan visualiasi proses produksi yang ada di industri dan menggambarkannya dengan desain 3D (3-Dimensi) dengan bantuan software Solidworks yang digunakan untuk menggambarkan kebutuhan benda serta software Ultra Cura yang digunakan pada alat printer 3D dalam proses pencetakan benda.

\section{METODOLOGI PENELITIAN}

Langkah-langkah yang dilakukan dalam perancangan maket proses produksi (mold production process) dengan mesin 3D (3-Dimensi) printing ini dilakukan seperti pada Gambar 1. melalui tahapan diantaranya:

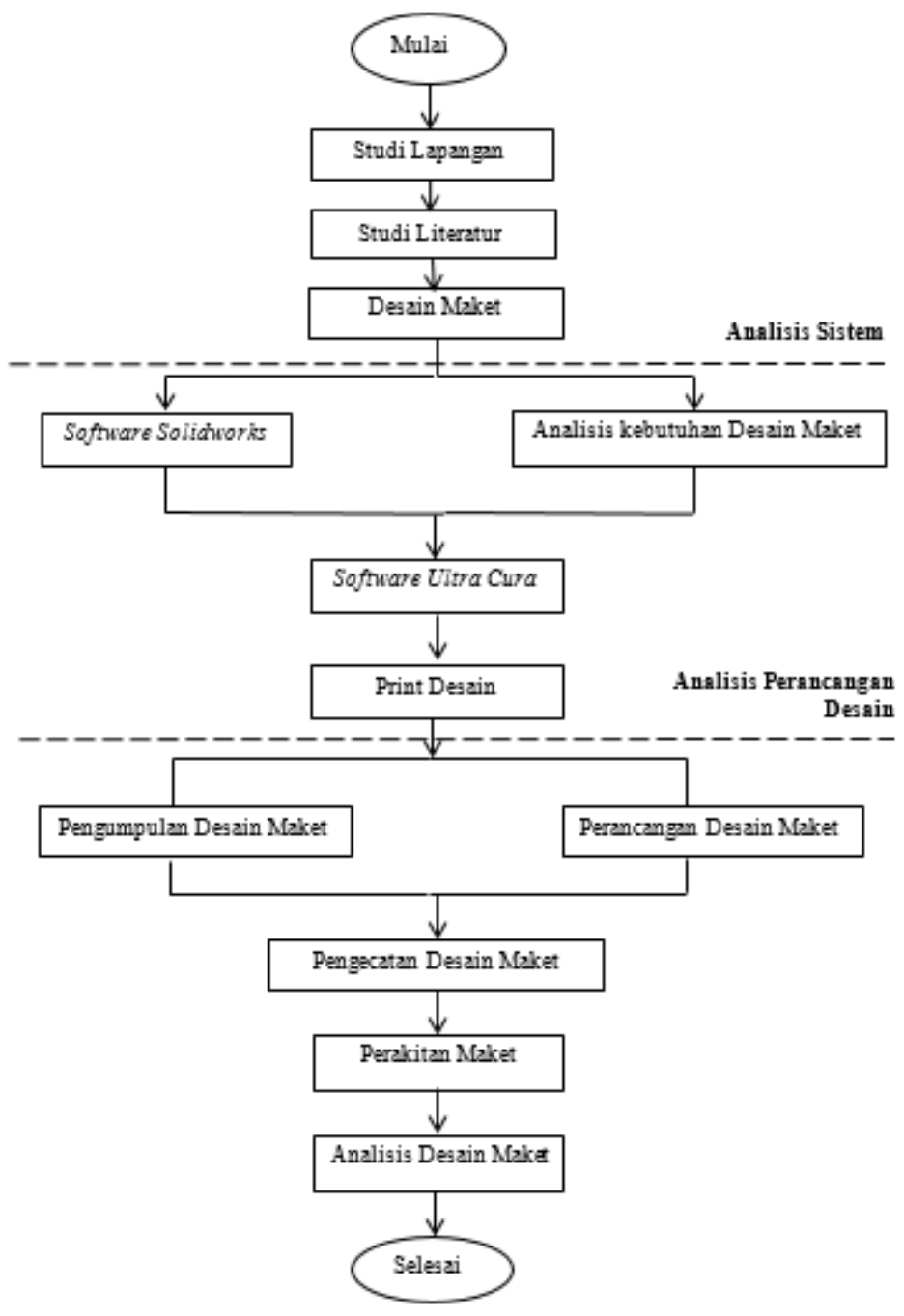

1. Studi lapangan

Gambar 1. Alur Perancangan

Kegiatan ini dilakukan dengan mengumpulkan informasi secara langsung melalui pegawai yang bekerja di salah satu perusahaan industry mold untuk mendapatkan informasi kebutuhan fasilitas dalam merancang tata letak produksi.

2. Studi literatur 
Kegiatan ini dilakukan dengan mencari sumber sebagai kajian ilmiah terkait beberapa tipe tata letak yaitu diantaranya: 1) Tata letak fasilitas berdasarkan aliran produksi (production line product atau product layout); 2) Tata letak fasilitas berdasarkan lokasi material tetap (fixed material location lay out atau fixed position layout); 3 ) Tata letak fasilitas berdasarkan kelompok produk (product family, product layout atau group technology layout); dan 4) Tata letak fasilitas berdasarkan fungsi atau semacam proses (fungtional atau procces lay out) (Huda, 2020). Berdasarkan tipe tata letak ini dipilih salah satu yaitu tipe berdasarkan aliran produksi (production line product atau product layout) untuk menggambarkan layout atau setiap susunan mesin dan peralatan produksi pabrik (Assauri, 2011).

3. Desain maket dengan analisis sistem dan analisis perancangan desain

Proses desain menggunakan pemanfaatan additive manufacturing yaitu memadukan software desain dengan software 3D (3-Dimensi) printing yaitu Solidworks dan Ultra Cura.

4. Perakitan dan analisis tata letak

Kegiatan ini dilakukan sesuai dengan pemilihan tipe tata letak yang digunakan yaitu aliran produksi dimana mesin dan fasilitas produksi lainnya akan diatur menurut prinsip "machine after machine" yang diletakkan berdasarkan garis (flow line) dari proses produksi tersebut

\section{HASIL, ANALISA DAN PEMBAHASAN}

\subsection{Perancangan Layout 2-D}

Perancangan desain maket diawali dengan membuat kerangka 2D (2-Dimensi) menggunakan software Solidworks Drawing. Desain bertujuan untuk menentukan bentuk dari maket yang akan dibuat seperti yang ditampilkan pada Gambar 2.

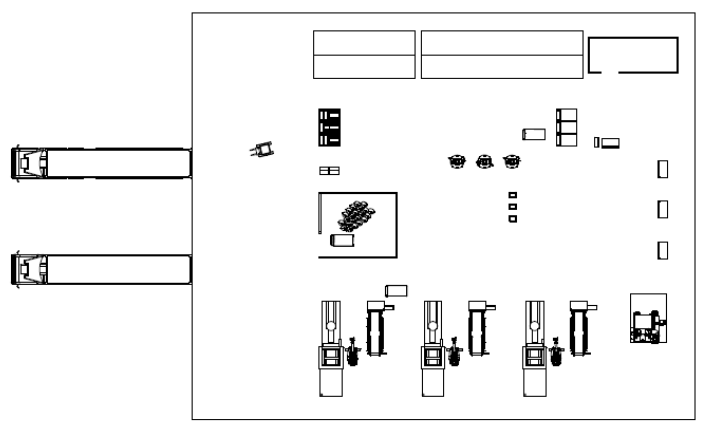

Gambar 2. Perancangan Layout 2D (2-Dimensi)

\subsection{Perancangan Layout 3-D}

Setelah tahap desain layout selesai, maka tahap selanjutnya adalah desain maket menggunakan software Solidworks tampilan 3D (3-Dimensi) beserta layout yang digunakan, diantaranya beberapa desain yang dibutuhkan untuk pembuatan maket ini adalah terlihat pada Gambar 3. sebagai berikut:

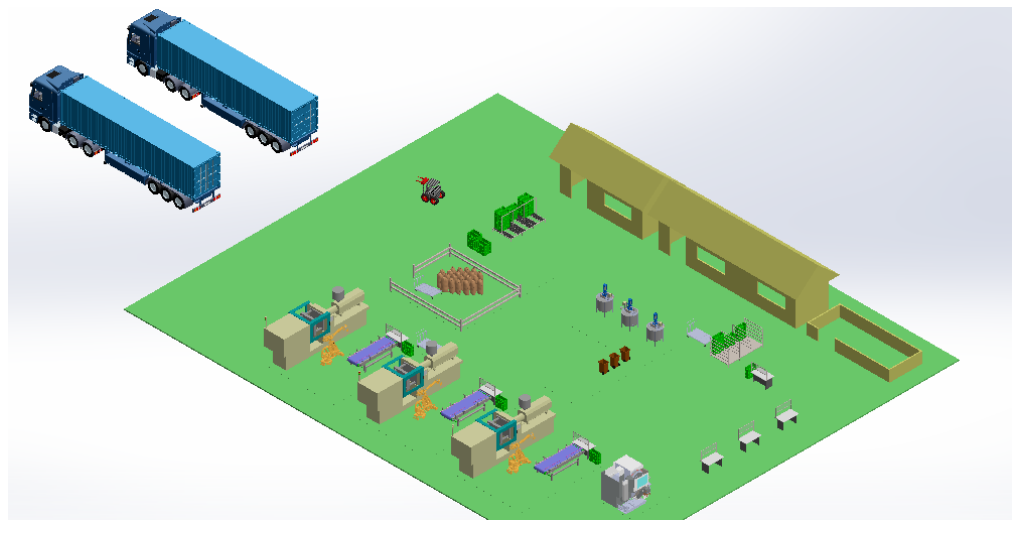

Gambar 3. Perancangan Layout 3D (3-Dimensi) 
Dalam desain layout proses produksi ini terdapat beberapa bagian desain yang dibutuhkan dalam desain maket diantaranya:

1. Mesin Injection Molding, lengan Robot dan Conveyor yang ditampilkan pada Gambar 4. Pada gambar ini terdapat tiga bagian keterangan gambar diantaranya:

1) Mesin injection molding terdiri dari mesin mold yang berfungsi untuk membuat cetakan atau produk yang telah ditentukan oleh perusahaan.

2) Lengan robot otomatis yang berfungsi untuk mengambil cetakan dari mesin injection molding.

3) Conveyor yang berfungsi untuk mengalirkan produk jadi kepada manpower atau quality control.

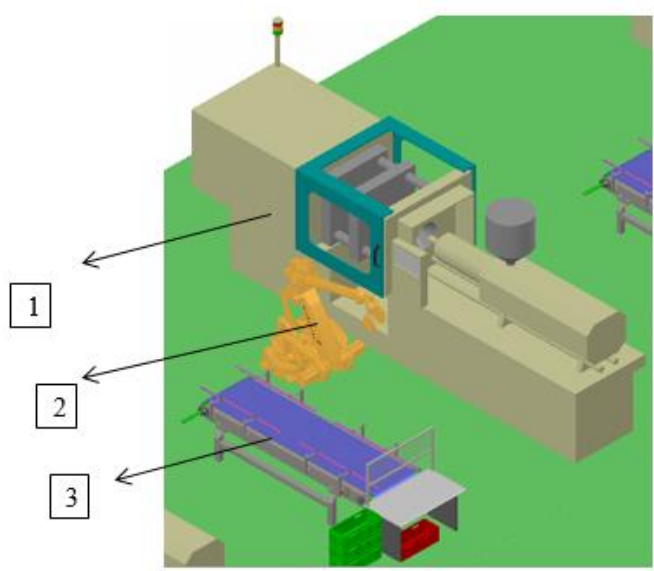

Gambar 4. Mesin Injection Molding, lengan Robot dan Conveyor

2. Desain Mix Area dan CNC Mold Injection yang ditampilkan pada Gambar 5.
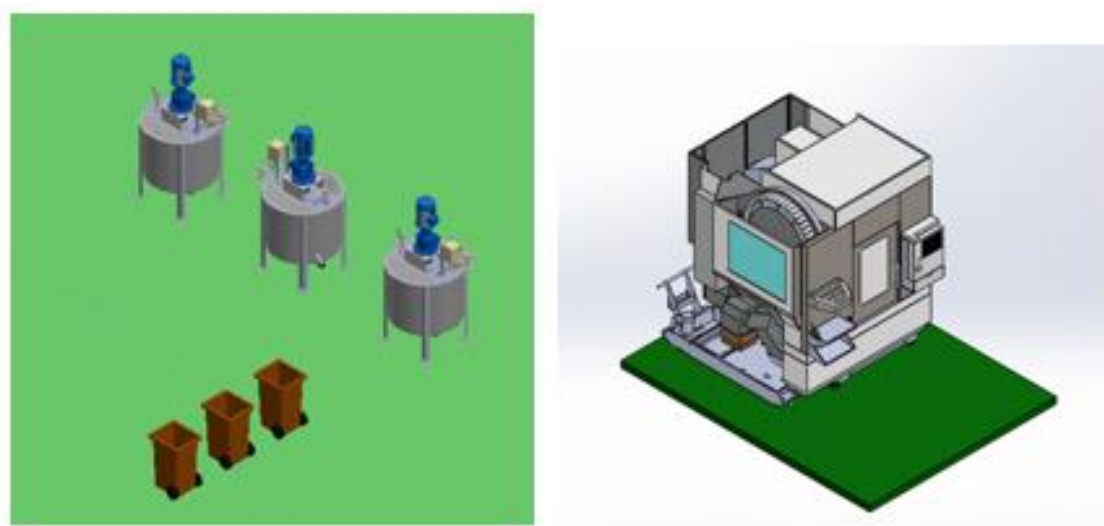

Gambar 4. Mix Area dan CNC Mold Injection 
3. Desain Forklift, Troly dan Shipping Area
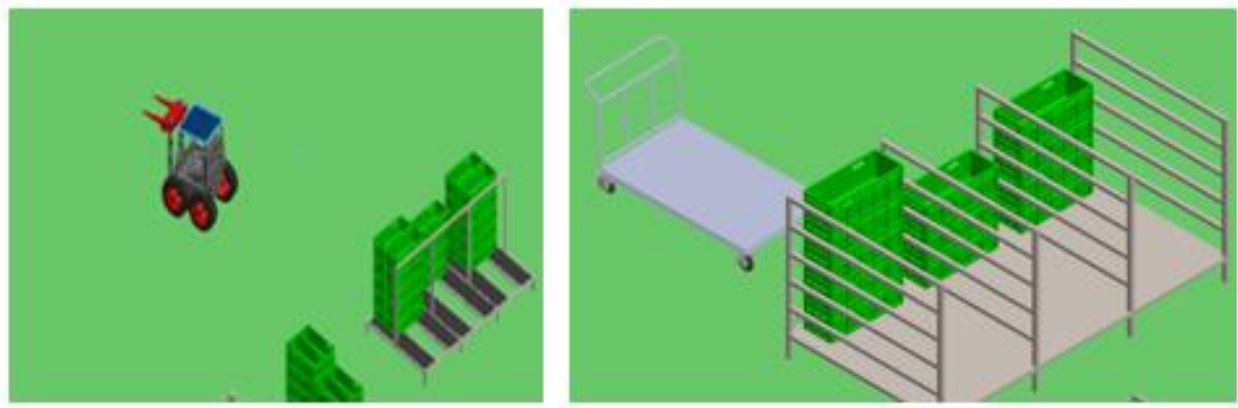

Gambar 5. Forklift, Troly dan Shipping Area

4. Desain Meja Quality Control, Assembly dan Box
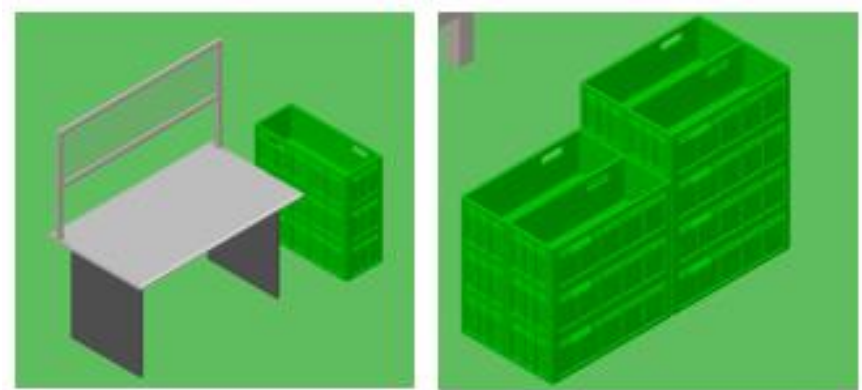

Gambar 6. Meja Quality Control, Assembly dan Box

5. Desain Layout Final

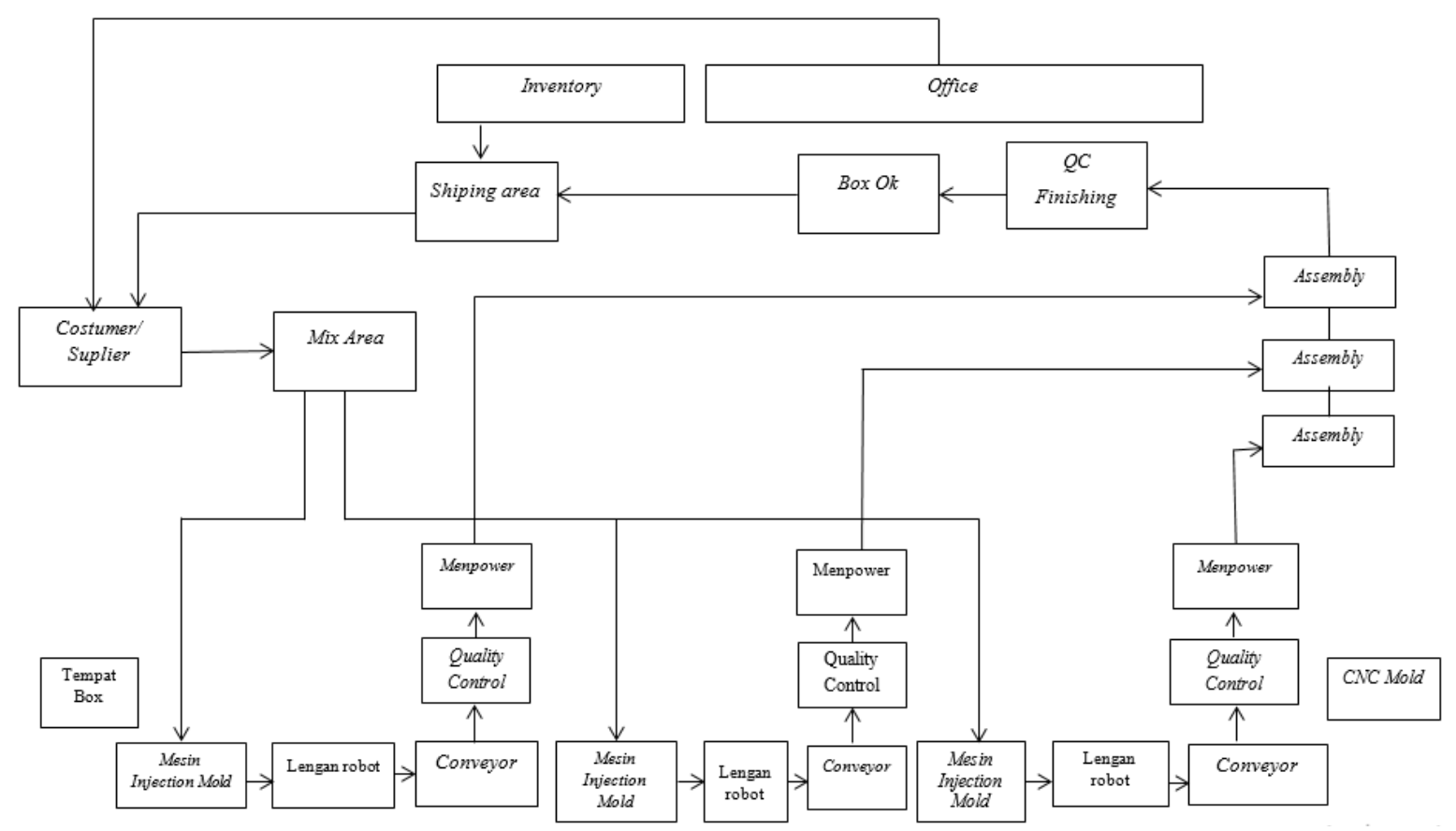

Gambar 7. Desain Layout Proses Produksi 


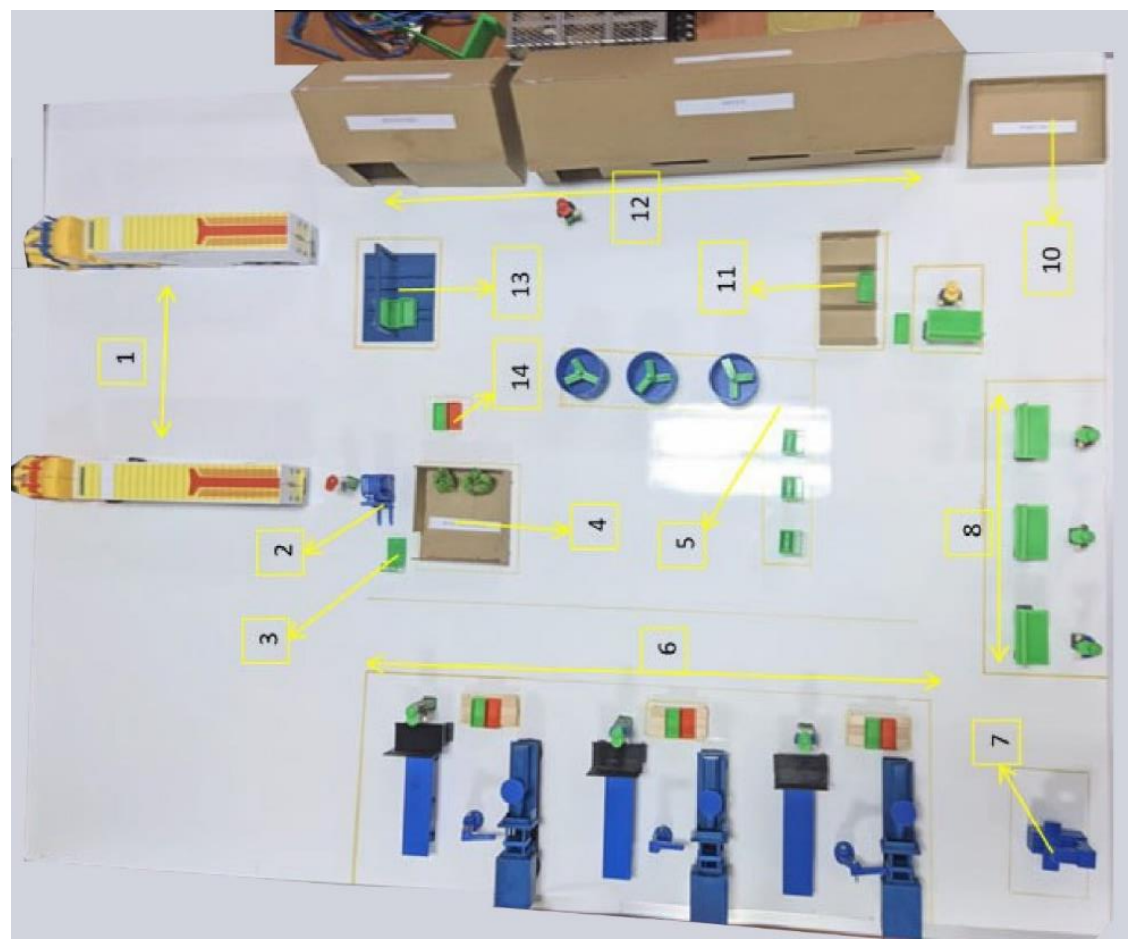

Gambar 8. Layout Final

1. Bagian dari mobil supplier dan mobil customer.

2. Bagian dari mobil forklift yang digunakan untuk menangkut material dari supplier.

3. Bagian dari desain troly atau alat yang digunakan untuk membawa material.

4. Bagian dari tempat raw material yang digunakan untuk tempat penyimpanan semntara ketika material datang.

5. Bagian dari mix area yaitu proses beberapa penyampuran raw material menjadi satu.

6. Bagian dari line proses produksi, terdapat beberapa proses diantaranya
a. Proses pencetakan produk plastik dengan mesin injection molding'
b. Proses pengambilan yang terotomasi dengan menggunakan lengan robot.
c. Proses pengiriman menggunakan conveyor
d. Proses pengecekan pada meja quality control oleh manpower
e. Terdapat pula box, dimana part $(O K)$ akan dimasukan pada box yang berwarna merah sedangkan part $(N G)$ akan dimasukan kepada box berwarna merah.

7. Bagian dari mesin cnc mold atau cetakan pembuat desain mold.

8. Bagian dari assembly part yang sudah dibuat.

9. Bagian dari quality control finishing

10. Bagian dari tempat pembuangan part $N G$ yang nantinya akan didawur ulang kembali.

11. Bagian dari tempat store finish good atau tempat penyimpanan akhir part yang layak dikirim ke customer. 
12. Bagian dari tempat inventory atau gudang penyimpanan, serta bagian tempat office yang dimana semua aktifitas perkantoran berjalan.

13. Bagian dari shipping area atau tempat dimana part yang akan dikirim kepada customer.

14. Bagian dari tempat atau lokasi penyimpanan box yang kosong.

\section{KESIMPULAN}

Berdasarkan hasil penelitian perancangan maket proses produksi (mold production process) dengan mesin 3D (3-Dimensi) printing sebagai media pembelajaran, dapat diambil kesimpulan bahwa melalui maket dapat mempermudah proses pembelajaran, sehingga mahasiswa dapat melihat, bahkan mengubah tata letak tersebut sesuai dengan fungsi dari pembelajaran. Beberapa mata kuliah yang dapat menggunakan media maket ini diantaranya pengantar teknik industri, perencanaan tata letak, desain proses produksi, dan juga perencanaan produk. Dimana mahasiswa, dapat mengubah tata letak dari maket untuk mengimprovisasi pengamatan pada proses pembelajaran.

\section{DAFTAR PUSTAKA}

Assauri, S. (2011) Manajemen Pemasaran. Jakarta: Rajawali Press.

Djamarah, S. B. and Zain, A. (2006) Strategi Belajar Mengajar. Jakarta: Rineka Cipta.

Hakim (2009) Desain Maket. Jakarta: Fakultas Ekonomi, Universitas Sebelas Maret.

Heizer, J. and Render, B. (2009) 'Manajemen operasi', in 1. 8th edn. Jakarta: Salemba Empat.

Huda, N. (2020) Rancangan Tata Letak Gudang dengan Penerapan Metode Shared Storage Guna Meningkatkan Efektivitas Penyimpanan Bahan Baku. Universitas Muhammadiyah Magelang.

Suminar, L. A., Wahyudin and Nugraha, B. (2020) 'Analisis Perancangan Tata Letak Pabrik PT. XYZ dengan Metode Activity Relationship Chart (ARC)', Jurnal Sains dan Teknologi, 2(2), pp. 181190. doi: http://dx.doi.org/10.36275/stsp.v20i2.276.

Wignjosoebroto, S. (2009) Tata Letak Pabrik dan Pemindahan Bahan. Surabaya: Guna Widya. 